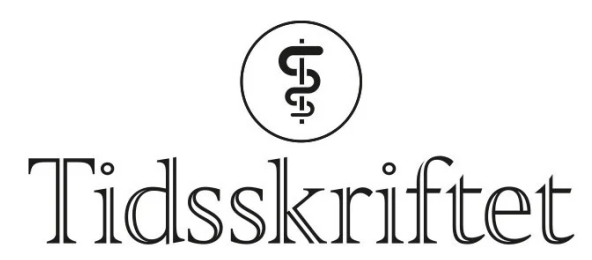

DEN NORSKE LEGEFORENING

\title{
Tidlig nevrokirurgisk intervensjon ved akutt bakteriell meningitt
}

DEBATT

\author{
JENS OTTO MAHLEN \\ jmaehlen@hotmail.com \\ Jens Otto Mæhlen er spesialist i anestesiologi, ansatt ved Luftambulanseavdelingen, Oslo \\ universitetssykehus og Anestesiavdelingen, Akershus universitetssykehus. \\ Forfatteren har fylt ut ICMJE-skjemaet og oppgir ingen interessekonflikter.
}

\section{WILLIAM OTTESTAD}

William Ottestad er spesialist i anestesiologi, forsker i traumatologi og overlege ved Luftambulanseavdelingen, Oslo universitetssykehus.

Forfatteren har fylt ut ICMJE-skjemaet og oppgir ingen interessekonflikter.

\section{HALDOR SLETTEB $\varnothing$}

Haldor Slettebø er tidligere overlege ved Nevrokirurgisk avdeling, Oslo universitetssykehus, pensjonert 2021, men er fortsatt aktiv i nevrokirurgisk forskning. Forfatteren har fylt ut ICMJE-skjemaet og oppgir ingen interessekonflikter.

\section{Det er behov for retningslinjer for akutt nevrokirurgisk behandling av forhøyet intrakranialt trykk ved akutt bakteriell meningitt.}

Akutt bakteriell meningitt er en tilstand med høy dødelighet, der hjerneherniering er den vanligste dødsårsaken (1). Svenska infektionsläkarföreningen publiserte i 2020 oppdaterte retningslinjer for behandling av akutt bakteriell meningitt (2). Disse retningslinjene fremhever viktigheten av tidlig diagnostikk med lumbalpunksjon og gir anbefalinger for hvilke pasienter som bør tilbys nevrokirurgisk behandling ved forhøyet intrakranialt trykk. Drenasje av cerebrospinalvæske og invasiv måling av intrakranialt trykk er anbefalt, som i tidligere retningslinjer. Etter innføringen av disse i 2010 har Sverige hatt en vedvarende lav

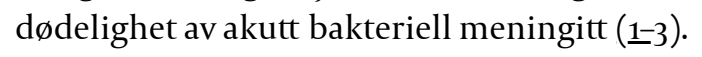

\section{Diagnostikk og behandling}


Forhøyet intrakranialt trykk og hjerneherniering kan inntre få døgn etter symptomdebut (1). Tiltak for å senke intrakranialt trykk og bevare tilfredsstillende cerebral perfusjon tidlig i forløpet kan derfor være avgjørende for prognosen. Den kraftige trykkstigningen som kan sees ved akutt bakteriell meningitt, skyldes utvikling av hjerneødem og økt volum av cerebrospinalvæske (2 2 ). I flere studier er det rapportert om dødelighetsreduksjon ved bruk av cerebrospinalvæskedrenasje hos pasienter med akutt bakteriell meningitt og forhøyet intrakranialt trykk $(\mathbf{1}, 4$.$) . Trykkreduksjon ved slik drenasje er en veletablert intervensjon$ ved traumatisk hodeskade, subaraknoidalblødning og kryptokokkmeningitt.

\section{«Lumbalpunksjon bidrar ikke bare til diagnostikk, men kan også gi oss et estimat for intrakranialt trykk gjennom måling av åpningstrykket $i$ spinalrommet»}

Akutt bakteriell meningitt er en tilstand som kan utvikle seg raskt, og tidlig diagnostikk er viktig. CT-undersøkelse er tidkrevende og forsinker diagnostikk og behandling (5). Normale funn ved CT-undersøkelse er vanlig hos meningittpasienter med forhøyet intrakranialt trykk, og flere studier har vist at CT ikke kan brukes for å utelukke dette (ㅎ-8). I svenske retningslinjer har man med noen få unntak fjernet kravet om obligatorisk CTundersøkelse før lumbalpunksjon hos pasienter med nedsatt bevissthet. Dette har bidratt til tidligere lumbalpunksjon, raskere igangsetting av korrekt behandling - og redusert dødelighet (5). Lumbalpunksjon bidrar ikke bare til diagnostikk, men kan også gi oss et estimat for intrakranialt trykk gjennom måling av åpningstrykket i spinalrommet (9.).

\section{Kunnskapsgrunnlag}

I en svensk prospektiv, kontrollert intervensjonsstudie fant man at nevrointensivbehandling med måling av intrakranialt trykk og cerebrospinalvæskedrenasje bedret overlevelsen ved akutt bakteriell meningitt (1). Pasientene i studien var i alderen 16-75 år og hadde bekreftet akutt bakteriell meningitt og Glasgow Coma Scale-skår $\leq 10$. I intervensjonsgruppen var dødeligheten $10 \%$, mot 30 \% i kontrollgruppen. Det tilsvarer en relativ risikoreduksjon på $68 \%$. Andelen pasienter med nevrologisk sekvele var $32 \% \mathrm{i}$ intervensjonsgruppen, mot $54 \% \mathrm{i}$ kontrollgruppen. Behandlingen som intervensjongruppen mottok, er svært lik den som anbefales i de svenske retningslinjene $(\underline{1}, \underline{2})$.

I en mindre, retrospektiv studie fra Canada kunne man vise til lignende resultater etter bruk av lumbal drenasje hos pasienter med akutt bakteriell meningitt og redusert bevissthet (4.). Ingen alvorlige komplikasjoner ble dokumentert i noen av studiene.

\section{Behov for nye retningslinjer i Norge}

Vi er av den oppfatning at de nevnte dataene fra Sverige er av høy kvalitet og underbygges av et sterkt patofysiologisk grunnlag for den intervensjonen som er evaluert. I Norge tilbys trykksenkende behandling ved nevrokirurgisk senter bare sporadisk, og vi mangler klare retningslinjer for hvilke pasienter som skal overflyttes. Kunnskap og erfaring rundt slik nevrokirurgisk behandling vil være begrenset hos de involverte i behandlingskjeden, ettersom akutt bakteriell meningitt er en sjelden tilstand.

Tidlig overflytting for trykksenkende behandling kan være avgjørende, da intrakranialt trykk kan stige raskt. De svenske retningslinjene inneholder klare kriterier for hvilke meningittpasienter som bør vurderes for slik behandling. Vi oppfordrer det 
nevrokirurgiske fagmiljøet til å etablere en faglig veiledning for overflytting og behandling av pasienter med akutt bakteriell meningitt og tegn på forhøyet intrakranialt trykk, og vi mener de svenske retningslinjene kan fungere som et utgangspunkt for dette arbeidet.

\section{REFERENCES}

1. Glimåker M, Johansson B, Halldorsdottir $\mathrm{H}$ et al. Neuro-intensive treatment targeting intracranial hypertension improves outcome in severe bacterial meningitis: an intervention-control study. PLoS One 2014; 9: eg1976. [PubMed][CrossRef]

2. Svenska infektionsläkarföreningen. Vårdprogram. Bakteriella CNS-infektioner. Revidert 2020. https://infektion.net/wp-content/uploads/2021/11/red-vardprogram-bakt-cns-inf-211129.pdf Lest 4.2.2022.

3. Wettervik TS, Howells T, Hedberg AL et al. Intracranial pressure dynamics and cerebral vasomotor reactivity in community-acquired bacterial meningitis during neurointensive care. J Neurosurg 2021; 135: 1-9. [CrossRef]

4. Abulhasan YB, Al-Jehani H, Valiquette M-A et al. Lumbar drainage for the treatment of severe bacterial meningitis. Neurocrit Care 2013; 19: 199-205. [PubMed][CrossRef]

5. Glimåker M, Johansson B, Grindborg Ö et al. Adult bacterial meningitis: earlier treatment and improved outcome following guideline revision promoting prompt lumbar puncture. Clin Infect Dis 2015; 60: 1162-9. [PubMed][CrossRef]

6. Larsen L, Poulsen FR, Nielsen TH et al. Use of intracranial pressure monitoring in bacterial meningitis: a 10-year follow up on outcome and intracranial pressure versus head CT scans. Infect Dis (Lond) 2017; 49:356-64. [PubMed][CrossRef]

7. Winkler F, Kastenbauer S, Yousry TA et al. Discrepancies between brain CT imaging and severely raised intracranial pressure proven by ventriculostomy in adults with pneumococcal meningitis. J Neurol 2002; 249: 1292-7. [PubMed][CrossRef]

8. April MD, Long B, Koyfman A. Emergency Medicine Myths: Computed Tomography of the Head Prior to Lumbar Puncture in Adults with Suspected Bacterial Meningitis - Due Diligence or Antiquated Practice? J Emerg Med 2017; 53:313-21. [PubMed][CrossRef]

9. Kapadia FN, Jha AN. Simultaneous lumbar and intraventricular manometry to evaluate the role and safety of lumbar puncture in raised intracranial pressure following subarachnoid haemorrhage. Br J Neurosurg 1996; 10: 585-7. [PubMed][CrossRef]

Publisert: 24. februar 2022. Tidsskr Nor Legeforen. DOI: 10.4045/tidsskr.22.0050

Mottatt 18.1.2022, godkjent 4.2.2022.

(C) Tidsskrift for Den norske legeforening 2023. Lastet ned fra tidsskriftet.no 26. april 2023. 